Tourism 2009, 19/1-2

\author{
Magdalena Miedzińska \\ Łódź University Library \\ mmagda433@wp.pl \\ Sławoj Tanaś \\ Łódź University \\ Institut of Urban Geography and Tourism \\ slatan@geo.uni.lodz.pl
}

\title{
THE TOURISM ATTRACTIVENESS OF POLISH LIBRARIES
}

\begin{abstract}
The aim of the article is to draw the reader's attention to the tourism attractiveness of renowned Polish libraries. These have attained a tourism function due to tourism exploration and penetration, but remain in the shadow of other Polish cultural assets. The article outlines the historical geography of Polish libraries, an analysis of tourism assets and an attempt to classify and catalogue libraries in Poland.
\end{abstract}

Key words: library, Poland, tourism attractiveness.

\section{INTRODUCTION}

To have an attraction is among the most important elements of tourism. It can be seen as the quality of a site, coming from its particular character and which stirs a tourist's interest (KUREK 2008). Tourism attractiveness can be universal or relative. So can a library be regarded as a tourism attraction? As with anything else, the tourism usefulness of sites must be considered individually. Certainly selected libraries which are important and valuable elements of the cultural landscape can be considered as a tourism asset, attraction, or even a product. After all, not every library will be interesting to tourists, just as not every church or factory will be. The authors believe that it is worth looking closer at the qualities that make some libraries attractive to tourists, as well as classifying and cataloguing them as tourism assets. The aim of this article is to draw readers' attention to the major Polish libraries which have attained a tourism function due to tourism exploration and penetration, but nevertheless remain in the shadow of other Polish cultural assets.

\section{THE HISTORICAL GEOGRAPHY OF LIBRARIES IN POLAND}

Until the 17th c. libraries in Poland developed similar to those in other European countries. Wars and the loss of independence in the $18^{\text {th }} \mathrm{c}$. caused the destructtion and confiscation of valuable book collections and they were also taken out of the country. Only after World War I, when Poland regained independence, did the collections start to be reconstructed and adjusted to new needs. Figure 1 presents the historical distribution of important libraries within the contemporary boundaries of Poland, including those which do not exist any more.

The tradition of Polish librarianship goes back to the Middle Ages when Mieszko I accepted Christianity and brought learned priests and monks to Poland. Apart from their pastoral duties, they undertook administrative, teaching and scholarly-cultural functions (e.g. as chroniclers). They founded monasteries with libraries and scriptoria, and schools for educating the priesthood. Such was the beginning of the cathedral library in Gniezno, considered to be the oldest in Poland (GRYCZ 1949), as well as the cathedral library in Płock (1024), and the Kraków cathedral library whose catalogues from the $12^{\text {th }} \mathrm{c}$. are the oldest such historical records preserved to the present day.

In the Middle Ages valuable book collections were kept in Benedictine, Cistercian, Dominican and Franciscan monasteries. Among the most famous are the Benedictine collections from Św. Krzyż, Tyniec and Lubiąż. None of the numerous and sometimes very rich monastic libraries has survived untouched (collections are stored in the monastic libraries of Tyniec and Mogiła, as well as in the seminary library in Pelplin). The cathedral (chapter house) and 


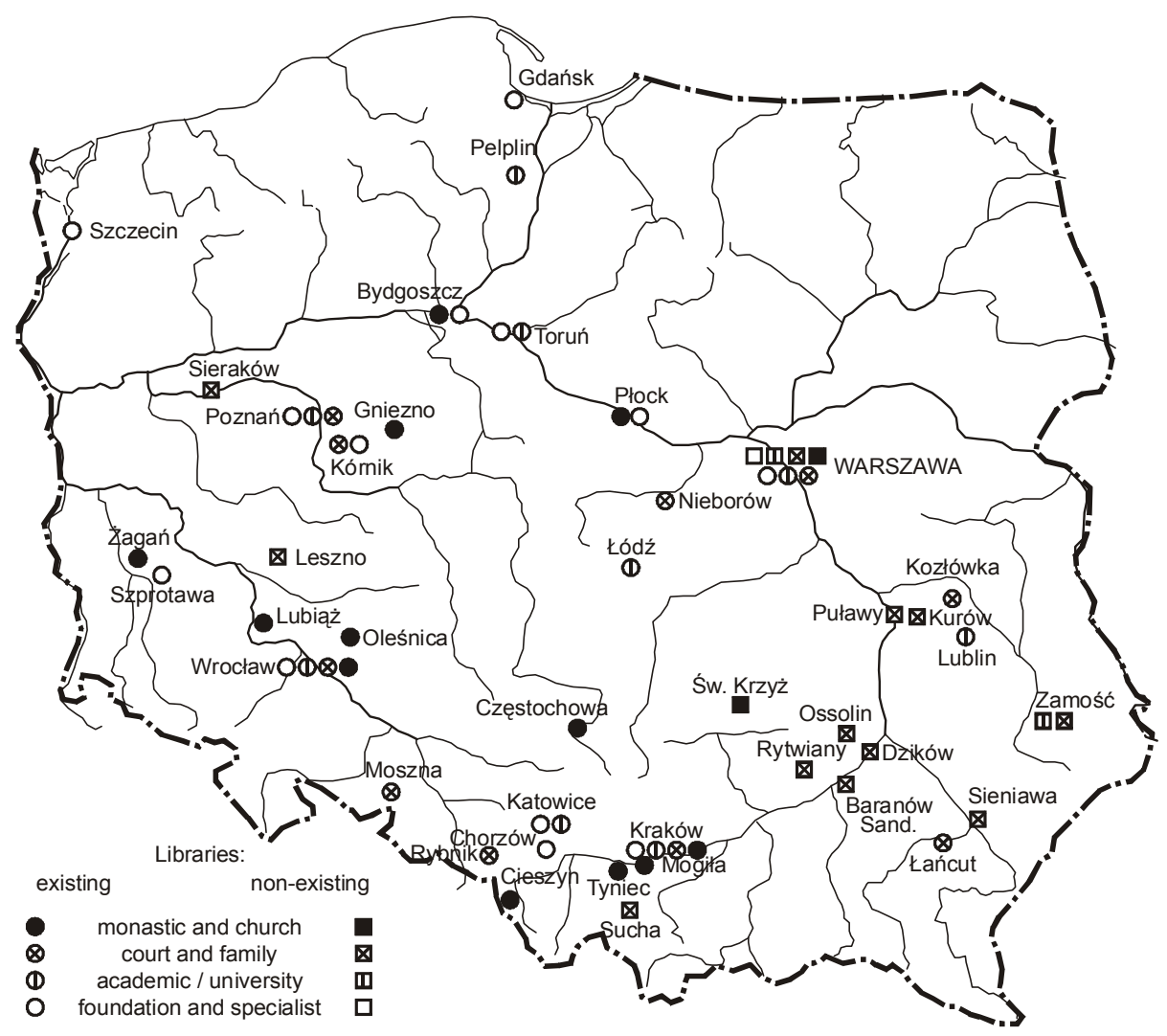

Fig. 1. Map of important libraries in Poland (s o u r c e: authors' compilation)

collegiate libraries which functioned in Poland from the $11^{\text {th }} \mathrm{c}$. met a similar fate.

A milestone in the history of Polish libraries was the establishment of the Kraków Academy in 1364. The Collegium Maius Library created in the $15^{\text {th }} \mathrm{c}$. was the germ of that of the Jagiellonian University.

The book culture which developed in medieval Poland flourished in the Renaissance period. Culture and scholarship left monastery walls, and the inventtion of printing popularized the purchase of books. Beautifully decorated private libraries appeared, set up by both rich merchants and the intelligentsia (BIEŃKOWSKA \& CHAMERSKA 1992). The most impressive collection belonged to King Sigismund Augustus II who continued the work of his father, Sigismund I. He collected 4000 volumes, beautifully bound, carefully ordered and stored. About 150 books from this collection have survived and they can be mainly found in the National Library in Warsaw (GRYCZ 1949).

In the Renaissance period, school and university libraries greatly developed. In the $16^{\text {th }} \mathrm{c}$., apart from the many books offered as gifts, the Kraków Academy Library received a large new home, known by its founder's name: 'Obiedziński Hall'. Nowadays it is visited by tourists. The Kraków Library was then the largest in Poland, possessing items of world value, and thus attracted numerous benefactors and visitors(!).

Thanks to benefactors' generosity, other libraries appeared at new universities: the Lubański Academy in Poznań (1519) and the Zamojski Academy in Zamość (1594). A network of high standard secondary schools with modern libraries was built by the Jesuits, e.g. the Vilnius College (Kolegium Wilenskie 1570). The abundant collection of the Vilnius Academy Library included a large part of Sigismund Augustus' book collection, in addition to the numerous books offered to the library as gifts.

The first libraries set up by city authorities also appeared at that time, e.g. Gdańsk Library, which still functions today and is known as the PAN (Polish Academy of Science) City Library in Gdańsk. Similar libraries were opened in Poznań (1535), Torun (1594) and some other large cities. This type of library did not become as popular in Poland as in more western states, due to the increasing economic weakness of our cities.

In the $17^{\text {th }} \mathrm{c}$. libraries changed from their medieval character. A library had the form of a large hall, with the collections placed on shelves or in closed cupboards along the walls. The shelves sometimes reached the ceiling, and in high rooms they were extended with galleries. The halls were decorated 
with columns, reliefs and paintings. As bibliophiles were also art lovers, it was commonly believed that a library should be similar to a museum. Sculptures and glass cases containing works of art and interesting curios were placed there (OŻARZEWSKI 1960, p. 93).

In the mid-17th $c$. Polish libraries went into a stagnation phase but the real disaster came as a result of the wars waged over Poland. The libraries suffered their greatest losses due to Swedish attacks in 1621-60, after which they never returned to their former splendour. The collections kept in churches and monasteries were confiscated. Neither royal, nor state nor private collections were saved. The more valuable items were taken out of the country to Swedish libraries (e.g. the Uppsala Library or the Royal Library in Stockholm), and many were damaged or lost (BIEŃKOWSKA 2005, 140). Private libraries and collections were in a relatively good situation. In the $17^{\text {th }} \mathrm{C}$ almost all magnate courts had libraries. Private collections were owned by the intelligentsia, nobility and landed gentry and an exquisite collection was in the hands of the Waza dynasty. King Jan III Sobieski was an expert bibliophile owning a collection which after his death was partly included in the public library in Warsaw by Andrzej Stanisław Załuski.

In the $17^{\text {th }}$ and $18^{\text {th }} \mathrm{c}$. libraries became permanent elements of aristocratic residences. We can quote many aristocratic book collections which are considered exceptional because of the number of volumes and the choice of literature. Valuable collections, going back several generations, were owned by the following families: Leszczyńscy (Baranów and Leszno), Żółkiewscy and Daniłowiczowie (Żułkiew), Potoccy (Warsaw, Kurów), Lubomirscy (Łańcut), Czartoryscy (Warsaw, Puławy, Sieniawa), Ossolińscy (Ossolina), Opalińscy (Rytwiany and Sieraków), Radziwiłłowie (Nieborów and Nieśwież), and others. The Radziwiłł books have survived until the present as one of the few examples of a court library preserved at its original site in the Nieborów palace.

All the achievements of private collectors, however, give way to the merits of the Załuscy brothers, who in 1745 created the first Polish public library in the Daniłowiczowski Palace in Warsaw. The founders' aim was to gather all Polish writing and the most important foreign books, and they more or less managed to achieve this aim. There are also records which prove that the library was visited by domestic and foreign tourists(!) (BIEŃKOWSKA 2005, p. 146). Thanks to the Załuscy, the enormous value of early examples of writing was realized, and people became interested in searching for and owning old volumes. Preserving Polish books was considered to be a patriotic duty in the face of threats to the independence of the state.
A genuine connoisseur and lover of books was King Stanisław August Poniatowski who gathered a collection of 16000 volumes in Warsaw, in a neoclassical hall in the library wing of the royal castle (Stanisławowska Library). Today the majority of this collection is in the University Library in Warsaw and in Kiev Library.

The loss of independence in 1795 was a terrible blow for Polish society and led to the destruction of all sources of knowledge, including libraries. Many valuable book collections suffered then. After the first partition of Poland in 1772 the Radziwiłł library was taken away from Nieśwież and included in the Public Library in St Petersburg. It was one of the largest private collections, containing about 20000 volumes. The loss of the Załuski Library in 1795 was a terrible blow for Poland with its resources becoming the foundation of the Tsar's Public Library also in St Petersburg. Many volumes were destroyed or lost then, and only small fragments of this collection have survived until our times. Many state, public and domestic libraries were taken abroad at that time while monastic libraries were plundered and destroyed.

In such hard conditions, individuals had an important mission to create book collections in order to preserve national writing for future generations. This duty was usually self-imposed by aristocrats who could devote their own money to organizing libraries. The most important family libraries set up in the 19th c. included: the Ossolinski Library (Lvov, and after the World War II in Wrocław - the Ossolineum), the Zamojski Estate Library (Zamość, later Warsaw), the Krasiński Estate Library (Warsaw), the Kórnicka Library of the Działyński family (Kórnik), the Raczyński Library (Poznań), the Czartoryski Library (Puławy, nowadays Kraków), the Branicki Library (Sucha), the Przeździecki Library (Warsaw), the Potocki-Branicki Library (the Wilanów Library transferred to the Wilanów Hall in the Krasiński Palace in Warsaw), and the Tarnowski Library (Dzikowo). These libraries have partly survived until today. The libraries of different scientific societies also played an important role, e.g. the library of the Warsaw 'Friends of Science' (the Sapieha family collection - partly taken out of the country to St Petersburg after the November Insurrection - 1830), the library of the Płock Scientific Association (reactivated in 1907, it took over the Zieliński collection of 20000 volumes, and still exists), or the library of the Torun Scientific Association (in 1923 the library was joined to the Municipal Library). the enormous role of university libraries, such as the Warsaw University Library, the Jagiellonian Library in Krakow, or the University of Lvov Library must not be forgotten either. 
Many valuable collections found refuge in monastic libraries, although they were plundered and their activity was severely limited under oppressors' rule. The greatest achievement of the interwar period was the opening of the National Library. Its resources were reinforced with the materials brought from the libraries in Rappersville and Batignolles, as well as with a considerable part of the Załuski Library, regained from the Soviet Union on the strength of the Riga Treaty (BIEŃKOWSKA 2005, p. 238).

Unfortunately, the most valuable Polish book collections were damaged or stolen during World War II, and only a small part of them were recovered. The total loss came to $85 \%$ in libraries and $70 \%$ in private collections (KoSMANOWA 1978, 40). The war put an end to family libraries; the collections which survived went to public libraries and state archives. The libraries that had survived the war were nationalized and after it the most important became the National Library in Warsaw which brought together many unique, historic books. Modern buildings were built for university libraries in Torun, Łódź and Lublin, and for the AGH (University of Science and Technology) in Kraków. Among the newest, with a very interesting architecture, are Warsaw University Library with a garden on the roof, and the Silesian Library.

The nationalization of magnate's estates badly affected the condition of the libraries (in the sense of rooms) in former palaces. In the damaged buildings and monasteries they were rarely rebuilt, though they were so precious for the cultural heritage of Poland. Nowadays, the few old libraries which have been preserved stir visitors' interest.

\section{THE LIBRARY AS A TOURISM ASSET}

Biblioteka - the Polish word for library - comes from Greek and means 'repository' (theka) of 'books' (biblios), an institution which collects books and makes them available to the public. In Poland in the $16^{\text {th }}$ and $17^{\text {th }} \mathrm{c}$. such a place was also called 'libraryja' or 'książnica'. Nowadays libraries are organized socio-cultural institutions, consisting of book collections, stores, reading rooms and lending sections. Libraries can be divided according to their character (academic, universal, school), ownership (church, monastery, public, private), topics (general, special), territorial range (e.g. national, regional, local) (Birkenmajer et al. 1971). A library is primarily a building, often architecturally distinct, with a variety of functions; or a number of rooms, adapted for storing and lending books. The situation, size, furnishing and functionality of a library used to be determined by the changing form of the book, the quantity of books, architectural styles and construction techniques, as well as the role and tasks it performed.

The functions of libraries changed over the centuries. Originally books and maps were only collected and ordered while at present the main task is to satisfy the reading needs and to inform. However, a library is often a museum and an art repository and therefore even the earliest libraries were treated as buildings worth visiting. There are reports in literature which demonstrate the tourism interest in libraries, e.g. in the $16^{\text {th }}$ c. Piotr Skarga praised the assets of the Vatican Library, and the Załuski Library was a major attraction in Warsaw in the $18^{\text {th }}$ c. (KOSMANOWA 1978, BIEŃKOWSKA 2005).

At present, those libraries which have been preserved in their original form, or those with historical interiors and book collections, are recognized tourism attractions and sometimes play the role of tourism products. There are many examples of libraries in the world which are included in the tourism canon of a given city or region.

From a tourism point of view, a library can be visited for its collection (manuscripts, old prints, books, maps), architecture and interiors, or temporary exhibitions and cultural events. Therefore, a library can be interesting for a tourist and stimulate the development of a tourism space, and the tourist can be interested in the book collection or the library building itself.

What is the role of libraries in helping form tourism space? In a tourism typology journeys made for the purpose of learning can be distinguished (WARSZYŃSKA \& JACKOWSKI 1979, p. 24). In the general structure of medieval tourism, movements related to university and religious centres clearly dominated. In this way university and monastic libraries became interesting to visit as well.

In fact, tourism journeys to libraries can be included in educational or sightseeing tourism, and the libraries themselves can be classified as tourism assets. Tourism assets include architectural and historical monuments, contemporary characteristic academic- and culture-related buildings, as well as museums and art collections. Some libraries can certainly be included in this group, and many of them are presented to the standards of a tourism attraction.

Libraries can also be regarded as a special asset, interesting to, for instance, bibliophiles. KoŁODZIEJCZYK (1979) sees art as a 'cultural good', including the institutions that collect material culture goods and therefore libraries. Thus a library can be interesting to a tourist of cultural tourism, where the only or predominant motive is culture. It goes without saying that a book is a product of culture. A library 
belongs to cultural heritage, both as an architectural monument and as a place where written 'cultural goods' are collected.

Analyzing the typology of libraries according to different criteria, the authors suggest a tourism classification which, due to the interpenetration of functions and criteria, is indivisible. Considering the special character of Polish book collections, libraries can be classified in the following way:

- monastic libraries - usually closed to tourists, and only open after prior application, unique due to the destruction caused by the dissolution of monasteries in the $18^{\text {th }} \mathrm{c}$. and nationalization after World War II;

- church libraries (cathedral, collegiate, parish) usually closed to tourists, and only open after prior application. Cathedral libraries are unique for their old prints. Library rooms sometimes preserved in churches or buildings adjacent to churches;

- academic libraries (university, seminary, other institutions of higher education) - the oldest and the most modern libraries are open to visitors;

- court libraries (castle, palace, court, royal) enlarged by the consecutive owners of a castle or palace. They are usually library halls in historic buildings (museums), rarely in separate buildings. Unique because of war damage, usually emptied of books. Open to visitors.

- Family libraries (gentry, aristocratic, bourgeois) - belonging to individual families, who supported and enlarged the collections, in fact such libraries served the owners alone. At present they are very rarely found at the old family seats. They were divided among state libraries. Limited opportunity to visit;

- Foundation libraries (municipal, central libraries, scientific associations) - public libraries, often turned into municipal or województwo libraries, often seated in historic buildings. The book collections are gifts from private owners and institutions. Open to visitors.

- Specialist libraries (museum-libraries, parliament, national, hospital, specialist - e.g. musical, geographical, medical) - have unique and specialist collections, open to visitors or with limited visiting options.

It must be remembered that libraries organize permanent and temporary exhibitions which are often of interest to tourists. The following are the usual motives for tourist visits to libraries: aesthetic experience, educational, a 'meeting with history', a 'meeting with books', interest in architecture and art, interest in a given area (e.g. bibliophiles).

\section{LIBRARIES IN THE 'TOURISM SPACE' OF POLAND}

In publications on tourism geography or describing the tourism attractions of Poland, we rarely read about libraries classified as a tourism asset. It is not surprising because many assets recognized and visited by tourists are not recognized by the authors of tourism guides and publications. LIJEWSKI, MIKUŁOWSKI \& WYRZYKOWSKI (1992) include sites and aspects closely connected with everyday life, work and human activity in the anthropogenic or cultural asset group. What is produced in the process of historical development and often proves interesting to tourists. Despite this definition, libraries are missing from the list of Polish tourism assets, even though a library is a source of historical and cultural knowledge. Due to the historic value of its book collection, a library can be classified as a repository of national and cultural treasure. Many Polish libraries exhibit old prints, historical book collections, maps, drawings, etc. Exhibitions of writings, often thoroughly prepared and attested, attract not only bibliophiles, but also ordinary tourists who want to experience history. Early examples of Polish writing are collected in many libraries all over Poland in either temporary or permanent exhibits, e.g. 'Sakramentarz tyniecki' $\left(11^{\text {th }} \mathrm{c}\right.$.) and 'Psatterz floriański' (14 ${ }^{\text {th }}$ c.) in the National Library, 'Ewangeliarz gnieźnieński' (11'th c.) in the cathedral library in Gniezno, 'Ewangeliarz płocki' $\left(11^{\text {th }}\right.$ c.) in the Czartoryski Library in Kraków, and the 'Behem Codex' (16 c.) in the Jagiellonian Library.

In Poland only a few libraries are situated in historic buildings, have original décor and have books in an unchanged condition. Table 1 presents the most important, Polish libraries, in the authors' opinion, which are historical monuments and museums, and at the same time display collections of old books.

Among the highest valued libraries in Poland is the Kórnik Library, in Kórnik castle. Despite the fact that the décor is not too grand, the library is famous for its book collection. The historical library hall is visited by over 89000 tourists annually. The Czartoryski Library Museum in Kraków has a similar character. Among the few preserved aristocratic libraries are the Radziwiłł Library in Nieborów, Zamoyski Library in Kozłówka (almost 260000 visitors annually) and the Potocki Library in Łańcut (over 367000 visitors). Unique attractions are the monastic libraries in Zagan (the Augustine baroque library), on Jasna Góra (the Pauline library) and the Cistercian library in Mogiła. Due to its architecture and décor, the Raczyński Library in Poznań should be mentioned. Tourists also visit university libraries, 
T a b l e 1. Selected important libraries in Poland entered in the register of historical monuments, and museum-libraries (as of $16^{\text {th }}$ January 2009)

\begin{tabular}{|c|c|c|}
\hline Miejscowość & Library & Tourism classification \\
\hline Bydgoszcz & Municipal Libraryz & Foundation, monastic \\
\hline Chorzów & Mielecki hospital library ${ }^{Z}$ & specialist \\
\hline Cieszyn & Tschammer's Library & church \\
\hline Częstochowa & Pauline Library - Jasna Góra & monastic \\
\hline Gdańsk & Gdańsk Libraryz & foundation, specialist \\
\hline Katowice & Silesian Library (new building) & specialist \\
\hline Katowice & Silesian Library in Francuska Stz & specialist \\
\hline Kozłówka & Zamojski Castle Library & court, family \\
\hline Kórnik & Kórnicka Library PAN - castle in Kórnik ZM & court, family \\
\hline Kraków & University of Science and Technology Library & academic \\
\hline Kraków & Polish Academy of Learning Library (PAN) & foundation \\
\hline Kraków & Jagiellonian Library (Collegium Maius) & academic \\
\hline Kraków & Jagiellonian Library in Mickiewicza Stz & academic, specialist \\
\hline Kraków & Chapter House Library (Cathedral Museum) ${ }^{\mathrm{M}}$ & church \\
\hline Kraków & Pauline Library - Skałka & monastic \\
\hline Kraków & National Museum in Kraków - Czartoryski LibraryzM & family, specialist \\
\hline Łańcut & Potocki Castle Library & court, family \\
\hline Mogiła & Cistercian Library & monastic \\
\hline Moszna & Palace Library & court \\
\hline Nieborów & Radziwiłłów Palace Library & court, family \\
\hline Oleśnica & Chained Library at the castle church (currently Basilica Minor) & church \\
\hline Płock & Zieliński Library of the Płock 'Scientific Association'z & foundation \\
\hline Poznań & Raczyński Libraryz & foundation \\
\hline Poznań & University Libraryz & academic \\
\hline Rybnik & Psychiatric Hospital Library ${ }^{Z}$ & specialist \\
\hline Szczecin & Pomerania Library & foundation \\
\hline Szprotawa & Municipal Libraryz & foundation \\
\hline Toruń & Copernicus Municipal Library & foundation \\
\hline Tyniec & Monastic Library (known as the Great Ruin) ${ }^{\mathrm{Z}}$ & monastic \\
\hline Warszawa & Działyński Library in Solidarności Streetz & family \\
\hline Warszawa & Krasiński Library in Okólnik StreetZ & family \\
\hline Warszawa & Royal Library (Royal Castle complex) ${ }^{\mathrm{Z}}$ & court, family \\
\hline Warszawa & National Library - the Commonwealth Palace $\mathrm{ZM}$ & specialist \\
\hline Warszawa & Krasiński Estate Library (National Library division) & family, specialist \\
\hline Warszawa & Warsaw Technical University Library & academic \\
\hline Warszawa & Public Library in. Koszykowa Street ${ }^{Z}$ & foundation \\
\hline Warszawa & Parliament Library, Museum Department ${ }^{Z M}$ & specialist \\
\hline Warszawa & Warsaw School of Economics Library & academic \\
\hline Warszawa & University Library (new building) & academic \\
\hline Warszawa & University Library (Warsaw University complex) ${ }^{\mathrm{Z}}$ & academic \\
\hline Warszawa & Biblioteka Załuskich (the Kings' House) & family, foundation \\
\hline Warszawa & Zamoyski Library (Zamoyski Palace) ${ }^{Z}$ & family \\
\hline Warszawa & Library of Warsaw Musical Society MuseumzM & foundation, specialist \\
\hline Wrocław & Biblioteka kapitulna & church \\
\hline Wrocław & University Libraryz & academic \\
\hline Wrocław & Ossolinski National Library & family, foundation \\
\hline Wrocław & Na Piasku Augustine monastic complex library & academic \\
\hline Żagań & Augustine monastic library & monastic \\
\hline
\end{tabular}

$\mathrm{Z}$ buildings in the register of historical monuments entered as 'library'; $\mathrm{M}$ museum-libraries.

S o u r c e: Author's compilation and KOBiDZ.

such as the Collegium Maius Library in Kraków (23000 visitors annually), and the University Libraries in Poznań, Wrocław and Warsaw. A rarity among Polish libraries is the medieval chained library in Oleśnica. The buildings which used to house family libraries often remain interesting places for tourists to visit (e.g. the Zamoyski, Działyński,
Załuski and Krasiński Libraries). Other outstanding libraries, because of their collections, are the Ossolineum Library in Wroclaw, the National Library in the Commonwealth Palace in Warsaw, the Zieliński Library in Płock, and the evangelical Tschammer Library in Cieszyn. Each is visited by tourists, most of whom ask for a guide's 
commentary. The libraries mentioned above are only the most prominent examples. It should be remembered that many courts, castles, palaces, monasteries and churches have library halls of more or less complete original décor and book collection, and treated as a tourism attraction.

\section{CONCLUSIONS}

Nowadays aspects of culture are present in nearly all types of tourism, carrying an element of learning and emotional involvement. Culture tourism is marked by a variety of tourism reception areas which leads to advanced specialization. We cannot really talk about library tourism, as the scale of this phenomenon is not large, but many new types of tourism appear in the literature as a result of researchers' pursuits and detailed analyses of tourism interests, rather than the rational distinguishing of tourism groups, specializing in travel to given tourism assets.

The authors has tried to show that a library, which meets certain conditions, and has potential can be interesting for a tourist, can play the role of a tourism attraction and can become a tourism product. The list of selected important Polish libraries is to make the reader aware that a library is not only a place where we borrow or read books, but also a piece of material cultural heritage, and very often a fine architectural monument and museum.

Tourism is a type of cultural contact in which cultures interact, thus a tourism use of libraries may positively affect tourism attitudes. It is important to understand the significance of a book and the variety of functions played by the library. Trips to libraries may help to create the need for contact with a book and in this way to develop cultural, historical and geographical awareness. Preparing libraries for culture tourism, making book collections accessible to tourists, especially at the more significant libraries, is an important element of developing this awareness.

In the authors' view, the library and an analysis of tourism in libraries should be an element of research into culture tourism, as well as a subject of library science.

Translated by Ewa Mossakowska

\section{BIBLIOGRAPHY}

BIRKENMAJER, A., KOCOWSKI, B., TRZYNADLOWSKI, J., 1971, Encyklopedia wiedzy o książce, Zakład Narodowy im. Ossolińskich, Wrocław-Warszawa-Kraków, pp. 2874.

BIEŃKOWSKA, B., 2005, Książka na przestrzeni dziejów, Wydawnictwo CEBID, Warszawa, pp. 350

BIEŃKOWSKA, B., CHAMERSKA, H., 1992, Tysiac lat ksiażki i bibliotek w Polsce, Zakład Narodowy im. Ossolińskich, Wrocław, pp. 202.

GRYCZ, J., 1949, Historia bibliotek w zarysie, Spółdzielnia Wydawnicza „Chłopski Świat”, Warszawa, pp. 100.

KLUKOWSKI, B., 2005, Książnice Narodowe Świata, Wydawnictwo CEBID, Warszawa, pp. 147.

KOŁODZIEJCZYK, A., 1979, Rola elementów kultury w turystyce, Instytut Turystyki, Warszawa.

KosmanowA, B., 1978, Tysiąc lat bibliotek w Polsce, Zakład Narodowy im. Ossolińskich, Kraków, pp. 44.

KOWALCZYK, A., 2000, Geografia turyzmu, Wydawnictwo Naukowe PWN, Warszawa, pp. 287.

KUREK, W. (red.), 2007, Turystyka, Wydawnictwo Naukowe PWN, Warszawa, pp. 541.

LIJEWSKI, T., MIKUŁOWSKI, B., WYRZYKOWSKI, J., 1992, Geografia turystyczna Polski, PWE, Warszawa, pp. 303.

OżARZEWSKI, Cz., 1960, Zarys dziejów książki i księgarstwa, Wydawnictwo Poznańskie, Poznań, pp. 173.

WARSZYŃSKA, J., JACKOWSKI, A., 1979, Podstawy geografii turyzmu, Wydawnictwo Naukowe PWN, Warszawa, pp. 337. 